\title{
Improving Hydric Soil Identification in Areas Containing Problematic Red Parent Materials: a Nationwide Collaborative Mapping Approach
}

\author{
Sara C. Mack ${ }^{1}$ - Jacob F. Berkowitz ${ }^{2} \cdot$ Martin C. Rabenhorst $^{1}$
}

Received: 9 July 2018 / Accepted: 18 November 2018 / Published online: 12 December 2018

(C) The Author(s) 2018

\begin{abstract}
Hydric soil identification utilizes diagnostic morphologic features, including iron transformations, resulting from anaerobic conditions. However, soils derived from some red parent materials (RPM) fail to develop characteristic hydric soils morphologies, confounding hydric soil and wetland delineation. Laboratory and field methods addressing resistant RPM soils exist, but application remains limited by uncertainty regarding problematic RPM distribution. In response, a collaborative effort ( $>50$ participants) documented problematic RPM distribution across the contiguous United States. Specifically, $>1100$ samples from $>450$ locations underwent laboratory analysis using the Color Change Propensity Index to identify problematic RPM soils. Geospatial analysis linked verified problematic soils with associated geologic units and soil series, generating maps of RPM distribution. Potential problematic RPM was identified in the Northeast and Mid-Atlantic, Great Lakes, South-central, and Desert Southwest-Western Mountains (problematic RPM regions herein), encompassing diverse groups of soils and parent materials. Despite the observed variability in soil characteristics, results suggest that problematic RPM was consistently derived from sedimentary, hematite-rich red bed formations developed where deposition of terrestrial sediments occurred in near-shore, marginal-marine environments. Understanding problematic RPM soils distribution promotes the appropriate application of existing hydric soil field indicators, including F21 - Red Parent Material, thus improving approaches to hydric soil identification and wetland management.
\end{abstract}

Keywords Hydric soil $\cdot$ Red parent material $\cdot$ Wetland delineation $\cdot$ Sedimentary red beds

\section{Introduction}

\section{Hydric Soil Morphology and Problematic Hydric Soils}

The United States Army Corps of Engineers (USACE) wetland delineation manual and associated regional supplements provide technical guidance and procedures for identifying and

Electronic supplementary material The online version of this article (https://doi.org/10.1007/s13157-018-1114-6) contains supplementary material, which is available to authorized users.

Jacob F. Berkowitz

Jacob.F.Berkowitz@usace.army.mil

1 Department of Environmental Science and Technology, H.J. Paterson Hall, University of Maryland, College Park, MD 20742-5821, USA

2 US Army Corps of Engineers, Engineer Research and Development Center, Vicksburg, MS 39180, USA delineating wetlands (Environmental Laboratory 1987; Wakeley 2002). Accordingly, identification and delineation of wetlands utilizes a three-factor approach encompassing indicators of wetland hydrology (e.g., near surface, seasonally high water tables), hydrophytic vegetation (water-loving plants), and hydric soils. In general, each of these factors are identified using readily applicable field indicators (Environmnetal Laboratory 1987; Berkowitz 2011a; USACE 2012; Tiner 2016).

Hydric soils are defined as "soils that have formed under conditions of saturation, flooding, or ponding long enough during the growing season to develop anaerobic conditions in the upper part" (Federal Register 1994). These periods of saturation, when combined with soil-microbial activity and the depletion of oxygen, promote biogeochemical processes that result in morphological features particularly useful for wetland identification during both wet and dry periods (Craft 2000; USDA-NRCS 2017). Common hydric soil morphologic features include: 1) the accumulation of organic matter from reduced rates of microbial decomposition under anaerobic conditions; and 2) the reduction and dissolution of ferric iron 
followed by subsequent translocation and depletion of ferrous iron phases (Reddy and DeLaune 2008). In particular, these iron reaction processes result in the formation of redoximorphic features that account for the prevalence of low chroma, Fe-depleted matrix colors associated with many mineral wetland soils (Vasilas and Berkowitz 2016; Rabenhorst 2011). The characteristic morphologies associated with prolonged saturation and aerobic conditions form the basis of field indicators of hydric soils, providing rapid and reliable approaches to identifying hydric soils utilized as part of wetland delineation procedures (USDA-NRCS 2017; Berkowitz 2011b).

In some cases, however, wetland areas exhibit the presence of hydrophytic vegetation and wetland hydrology, yet lack typical hydric soil morphological features due to natural conditions (Environmental Laboratory 1987). These soils are called "problematic hydric soils" (Vepraskas and Sprecher 1997; Robinette et al. 2011). Common examples of problematic hydric soils include: soils with low iron and/or organic matter contents that preclude the formation of redoximorphic features, high alkalinity soils that inhibit iron transformations, and recently deposited soil materials that simply have not been in place long enough to develop characteristic hydromorphic properties (USACE 2012; Tiner 2016). Additionally, some problematic soils result from factors related to parent material characteristics. For example, soils derived from dark parent materials (e.g. black coal deposits) mask morphological patterns associated with soil wetness (Stolt et al. 2001; U.S. Army Corps of Engineers 2012). These problematic soils led to the development and use of several field indicators of hydric soils specifically addressing a particular phenomenon or landscape position (e.g., F19 - Piedmont Flood Plain Soils; S11 - High Chroma Sands; Berkowitz and Sallee 2011; USDA-NRCS 2017).

\section{Problematic Red Parent Material Soils}

It has long been recognized that soils derived from certain redcolored parent materials (RPM) fail to develop soil morphologies (i.e., Fe-depleted matrix colors) characteristic of most wetlands, even where prolonged soil saturation and anaerobic conditions occur (Mokma and Sprecher 1994). Wetland delineation practitioners identified RPM as one of the most common problematic soil situations, accounting for up to $20 \%$ of the difficult soil scenarios reported in a national dataset examining wetland evaluation procedures across the United States (Berkowitz 2011b). Guidance was developed as early as 1996 to aid in the identification of wetlands in soils derived from RPM, with additional strategies described in recently published regional supplements to the USACE wetland delineation manual (USACE 2012).

Previous and on-going research suggests that these problematic RPM soils exhibit resistance to color change due to mineralogical characteristics inherited from their parent materials (USDA-NRCS 2017), and therefore occur in association with particular geological formations. For example, Niroomand and Tedrow (1990) demonstrated that soils derived from red shales resisted color changes under both field and laboratory conditions compared with soils derived from the other formations within the same area of New Jersey. Red soils from stratigraphically-related formations in Maryland and Connecticut also lacked prominent redoximorphic features despite highly-reducing conditions observed during field studies (Elless et al. 1996; Rabenhorst 2011; Ford 2014). Similar findings were reported across a range of formation types and geographic locations including soil hydrosequences derived from red-colored lacustrine deposits in Michigan (Mokma and Sprecher 1994), clayey alluvial deposits derived from red beds in Louisiana (Rabenhorst and Parikh 2000), and glacio-lacustrine sediments in Minnesota and Wisconsin (Petersen et al. 1967; Wheeler et al. 1999).

While these case studies demonstrate that some red soils are problematic, the majority of red soils or soils derived from red-colored parent material readily form hydromorphic features under anaerobic conditions (Rabenhorst and Parikh 2000). For example, red soils derived from metabasaltic rocks high in ferromagnetic elements and soils derived from redcolored fluviodeltaic sands displayed no resistance to color change despite the presence of red colors indicative of parent materials with high iron content (Sirkin 1986; Schwertmann 1993). Further, red soils derived from metamorphic and paracrystalline rocks associated with the Congaree River floodplains in North and South Carolina also do not exhibit a resistance to color change, despite the predominance of colors often 5 YR or redder (USDA-NRCS 2017).

To explore the issue of color change resistance in red soils, Rabenhorst and Parikh (2000) developed a laboratory approach that distinguishes between red soils that were problematic (i.e. resistant to color change) and those that displayed color change propensity. In their study, red soils (both suspected problematic RPM and non-problematic RPM) were collected and treated with a sodium dithionite reducing agent in various treatments of differing periods of time and temperatures. Following treatments, digital colorimeter measurements documented shifts in Munsell color components (hue, value, chroma). Based on observed color changes, an equation quantifying the inherent capacity of the soils to form redoximorphic features (i.e. change color) under reducing conditions was developed; entitled the Color Change Propensity Index (CCPI). The CCPI groups soils into three categories: 1) non-problematic RPM soils displaying no color change resistance (CCPI values $>40$ ); 2) problematic RPM soils that resisted color change under reducing conditions (CCPI <30); and 3) an intermediate range with CCPI values in which soils displayed limited color change resistance representing a group of potentially problematic RPM (CCPI = $30-40$ ). The CCPI provided a procedure for quantitatively identifying problematic RPM, contributing to the development of a 
field indicator of hydric soils to help improve wetland delineation approaches in areas containing RPM.

\section{Development of F21 Red Parent Material}

In order to address hydric soil delineation challenges associated with problematic RPM soils, a field indicator of hydric soils was developed for use in areas containing RPM (F21 Red Parent Material). The F21 - Red Parent Material hydric soil field indicator requires (USDA-NRCS 2017):

A layer derived from red parent materials that is at least $10 \mathrm{~cm}$ (4 in.) thick, starting at a depth $\leq 25 \mathrm{~cm}$ (10 in.) from the soil surface with a [Munsell] hue of 7.5YR or redder. The matrix has a value and chroma greater than 2 and less than or equal to 4 . The layer must contain $10 \%$ or more depletions and/or distinct or prominent concentrations occurring a soft masses or pore linings. Redox depletions should differ in color by having:

a. a minimum difference of one value higher and one chroma lower than the matrix, or

b. value of 4 or more and chroma of 2 or less.

The F21 - Red Parent Material hydric soil field indicator is approved for use in portions of the mid-Atlantic, New England, and Appalachian mountains including Major Land Resource Area (MLRA) 127 of Land Resource Region (LRR) N, MLRA 145 of LRR R, and MLRAs 147 and 148 of LRR S. Notably, the indicator has also been approved for testing across the United States in all soils derived from RPM (USDA-NRCS 2017). As a result, the F21 - RPM indicator can be applied in any soil identified as containing problematic RPM. To that end the F21 - Red Parent Material hydric soil field indicator user notes incorporate the CCPI concept, limiting application to soils in which problematic RPM (i.e., CCPI <30) has been documented using laboratory testing. Additionally, current guidance highlights examples of derivative problematic RPM soils (e.g., residuum in the Piedmont Province Triassic lowlands, Paleozoic red beds of the Appalachian Mountains) promoting application within those areas.

Despite the advances in laboratory techniques and field indicator development related to problematic RPM, several obstacles continue to restrain utilization of F21 - Red Parent Material. First, field practitioners report limited experience and comfort differentiating between problematic RPM and other red soils. Second, prior to the current study, CCPI analysis was utilized on a case by case basis, precluding development large scale problematic RPM mapping. As a result, current guidance lacks a comprehensive list of confirmed problematic RPM locations throughout the country. For these reasons, field staff report a general reluctance to utilize F21 - Red Parent Material when making wetland determinations despite the persistence of problems related to RPM (Berkowitz 2011b).
In response, the USACE and the Pedology Research Laboratory at The University of Maryland, in cooperation with the United States Department of Agriculture - Natural Resources Conservation Service (USDA-NRCS) and Kellogg Soil Survey Laboratory (KSSL), began a nationwide soil mapping project to identify areas containing problematic RPM in support of the application of F21 - Red Parent Material. Study objectives include: 1) evaluating soils suspected to be associated with problematic RPM using CCPI analysis across a wide variety of soil and geologic settings, 2) correlating CCPI results with soil/geologic map units using spatial datasets, and 3) developing national and regional guidance maps for recommended application of F21 - Red Parent Material to improve hydric soil (and therefore wetland) identification across the country. Select examples of the geologic origin of problematic RPM are also provided within each section along with guidance on the application of study results. A comprehensive report on the geology and soils related to problematic RPM is provided in Mack (2018).

\section{Methods}

A national effort was coordinated between soil and wetland scientists from federal agencies, state/local agencies, universities, and the private sector. Letters of invitation were sent to all USDA-NRCS MLRA regional offices and USACE district offices to solicit participation among scientists and/or field personnel familiar with the RPM phenomenon to participate in the project. A cooperative arrangement was also established with KSSL permitting access to archived soil samples and associated data. The project was further promoted at conferences organized by the Soil Science Society of America and the National Cooperative Soil Survey. These efforts resulted in the collection and/or volunteer submission of $>1100$ soil samples from the contiguous United States over a 1.5 year period. Supplemental figures identify soil sampling and archival locations used to develop guidance maps.

All submitted soil samples were derived from geologic formations and/or parent material(s) potentially associated with problematic RPM. As a result, CCPI soils analysis could be correlated with geological data in the mapping phases of the project. Sampling included all red soils suspected of problematic RPM, irrespective of the presence of wetland conditions or field indicators of hydric soils (including F21 - Red Parent Material). This approach utilized the local knowledge of field professionals to obtain a broad representation of soils, as well as attempting to capture all possible inclusions of hydric soils that can occur in soil map units dominated by well drained soils to map the entire possible extent of problematic RPM. Based on the reports of potential RPM soils and their parent materials from participating scientists, additional soils were requested for analyses from the KSSL. 
Project participants provided a $500 \mathrm{~cm}^{3}$ sample from each horizon to a depth of $1 \mathrm{~m}$ to reflect properties of the entire soil profile and/or the soil's parent materials to the extent possible. Basic soil descriptions, containing horizon names, depths, colors, field textures, and the presence, contrast, and abundance of any redoximorphic features, were requested to accompany samples as described in Vasilas and Berkowitz (2016). Finally, site location (GPS coordinate), soil series, and any geological context (e.g., formation name, time period, rock type, etc.) were also requested.

All CCPI analyses followed methods outlined in Rabenhorst and Parikh (2000). Soils were dried, crushed, and sieved using a $2 \mathrm{~mm}$ (\#10) sieve. Two to three horizons (one from the surface, subsurface, and deeper subsurface) from each profile underwent CCPI analyses. Soil colors were measured using a KonicaMinolta digital colorimeter, with Munsell hue, value, and chroma recorded to the 0.1 unit. Soil color was measured on each sample under three different conditions: 1) after saturation with citrate buffer solution; 2 ) after treatment with citrate buffer solution and sodium dithionite at room temperature $\left(25^{\circ} \mathrm{C}\right)$ for $1 \mathrm{~h}$; and 3) after treatment with citrate buffer solution and sodium dithionite at $80{ }^{\circ} \mathrm{C}$ for $4 \mathrm{~h}$. Based on measured color data, a CCPI value was calculated for each sample to document if the soil was problematic RPM, non-problematic, or potentially problematic as described above. The mean CCPI value for all horizons samples was used to assign a single designation to each sample location. Some soils in which problematic RPM was positively identified ( 24 of $>450$ pedons) displayed CCPI results that differed by horizon; utilizing the mean value for each pedon may represent a potential limitation of this approach. Statistical testing evaluating difference in CCPI values between problematic, non-problematic, and potentially problematic RPM soils utilized one-way analysis of variance (ANOVA; $\alpha=0.05$ ) following testing for normality (Shapiro Wilk test) and homogeneity of variance (Levene's test; SPSS IBM, Inc. Version 20).

Following CCPI analysis, problematic RPM samples were linked with associated soil series and/or geologic formations using USDA-NRCS Official Series Descriptions (OSDs), Block Diagrams, Series Extent Maps, other available resources, as well as local knowledge from project participants. Specifically, a list of soil series associated with problematic RPM was generated using the following criteria: series with direct CCPI verification, published literature documenting problematic RPM, the OSD indicated geographic association with a CCPI verified series, or the soil series was derived from a USDA-NRCS Block Diagram composed of CCPI verified materials. Notably, feedback from experienced soil scientists familiar with the local distribution of problematic RPM was utilized to further refine the series list. Following the generation of the problematic RPM soil series lists, series names were joined to both the USDA-NRCS Digital Gridded U.S. General Soil Map (gSTATSGO2) and Gridded Soil Survey Geographic (gSSURGO) map units as found in the component tables for the map unit records using ArcGIS 10.4 software.

Additionally, parent materials and geological units associated with problematic RPM soil series were identified for mapping. Similar to the soil series approach described above, submitted samples were linked with geological units (as members, formations, groups, etc.) verified as containing problematic RPM, or those lithologically-associated with verified problematic RPM units. A geological unit was added to the list when: the geological unit was the parent material of a soil series identified as problematic RPM using CCPI, previously published literature identified the geological unit as problematic RPM, the geological unit was identified in the OSD of a verified soil series using CCPI data, the geological unit was associated with a verified problematic RPM series using USDA-NRCS Block Diagram, or the geological unit was mapped and was substantially overlain by a problematic RPM soil map unit in both USDA-NRCS gSTATSGO and gSSURGO databases. The USGS Mineral Science Program's Integrated Geologic map database for the United States was also utilized to define geologic features. Geologic units identified as problematic RPM were mapped predominantly by formation name within the US Geological Survey's (USGS) "Preliminary Integrated Geologic Map Databases for the United States" using ArcGIS 10.4 software.

Individual soils map units were identified as problematic RPM if the map unit contained $\geq 5 \%$ of a problematic RPM soil series, or corresponding geologic unit datasets suggested the presence of problematic RPM parent materials. As a result, national scale problematic RPM guidance maps represent the composite of both soils and geological information supported by CCPI analyses. Regional maps were also generated based on the locations of RPM occurrence across USDA-NRCS LRRs and MLRAs and USACE regional supplements. Draft problematic RPM maps were sent to affected USDA-NRCS MLRA offices and USACE district offices to solicit comment and feedback from field personnel familiar with local soil conditions. Following editing and comment response based upon user feedback, final guidance maps were generated for recommended application of field indicator F21 - Red Parent Material.

\section{Results and Discussion}

\section{National Overview}

More than 1100 individual soil samples, collected from $>450$ geographic locations within the contiguous United States, were analyzed for CCPI to investigate the spatial distribution of problematic RPM. Within the dataset, $51 \%$ of soils were characterized by CCPI values consistent with problematic RPM properties (i.e., color change resistance; CCPI $<30$ ), $19 \%$ displayed some resistance to color change (i.e., potential 
problematic RPM; CCPI 30-40), and 30\% consisted of soils were identified as non-problematic RPM (CCPI >40). Where present, problematic RPM soils displayed mean CCPI ( \pm standard deviation) of $19 \pm 6.1$, significantly lower $(p<0.001)$ than non-problematic soils $(\mathrm{CCPI}=66 \pm 35)$, and potentially problematic $(\mathrm{CCPI}=36 \pm 4.0)$ soils $(\mathrm{p}<0.001)$ examined. Similar statistical differences were found in each problematic RPM region discussed below. As a result, approximately 745 soil series and associations linked with 270 geologic formations displayed CCPI values consistent with potential problematic RPM conditions. Problematic RPM soils were associated with a wide variety of parent materials, with residual $(31 \%)$, alluvial (28\%), and till $(23 \%)$ sources most commonly observed. A variety of colluvial, lacustrine, erosional deposits and mixed parent materials also exhibited problematic RPM properties. Notably, despite the wide variety of parent materials observed, all samples identified as problematic RPM soils across the national dataset were associated with parent materials derived from red bed formations, as well as glacial, alluvial, and colluvial transported materials derived from red bed formations. Red beds include detrital, siliciclastic sedimentary rocks or sequences (e.g., conglomerates, sandstones, siltstones, shales) in which $\geq 60 \%$ of the total stratum displays red pigments resulting from ferric oxides, predominantly hematite. For more information on the characteristics, origins, or classification of red beds, see Krynine (1949); Van Houten (1973); Turner (1980); and Bigham et al. (1993).

Four problematic RPM regions have been identified where F21 - Red Parent Material application is recommended based on the occurrence of problematic RPM across various USACE regional supplement areas and USDA-NRCS LRRs (Fig. 1): Northeast and Mid-Atlantic, Great Lakes, South-Central, Desert Southwest and Western Mountains. The following section provides detailed maps and describes CCPI results within each of these four problematic RPM regions, yielding insight into the soil series and geologic formations identified, and problematic RPM locations within USACE regional supplements, USDA-NRCS LRRs and MLRAs. Tables provide lists of geologic features and soil series linked with problematic RPM. Guidance for the application of study results to identify hydric soils in areas containing problematic RPM is also discussed. Supplementary maps are also provided, displaying sampling locations within each region (Figs. S1-S5).

\section{Northeast and Mid-Atlantic}

Over 100 sample locations were analyzed for CCPI from the Northeast and Mid-Atlantic problematic RPM region confirming problematic RPM in two USACE regional supplement areas, five LRRs, and 14 MLRAs (Table 1; Fig. 2).

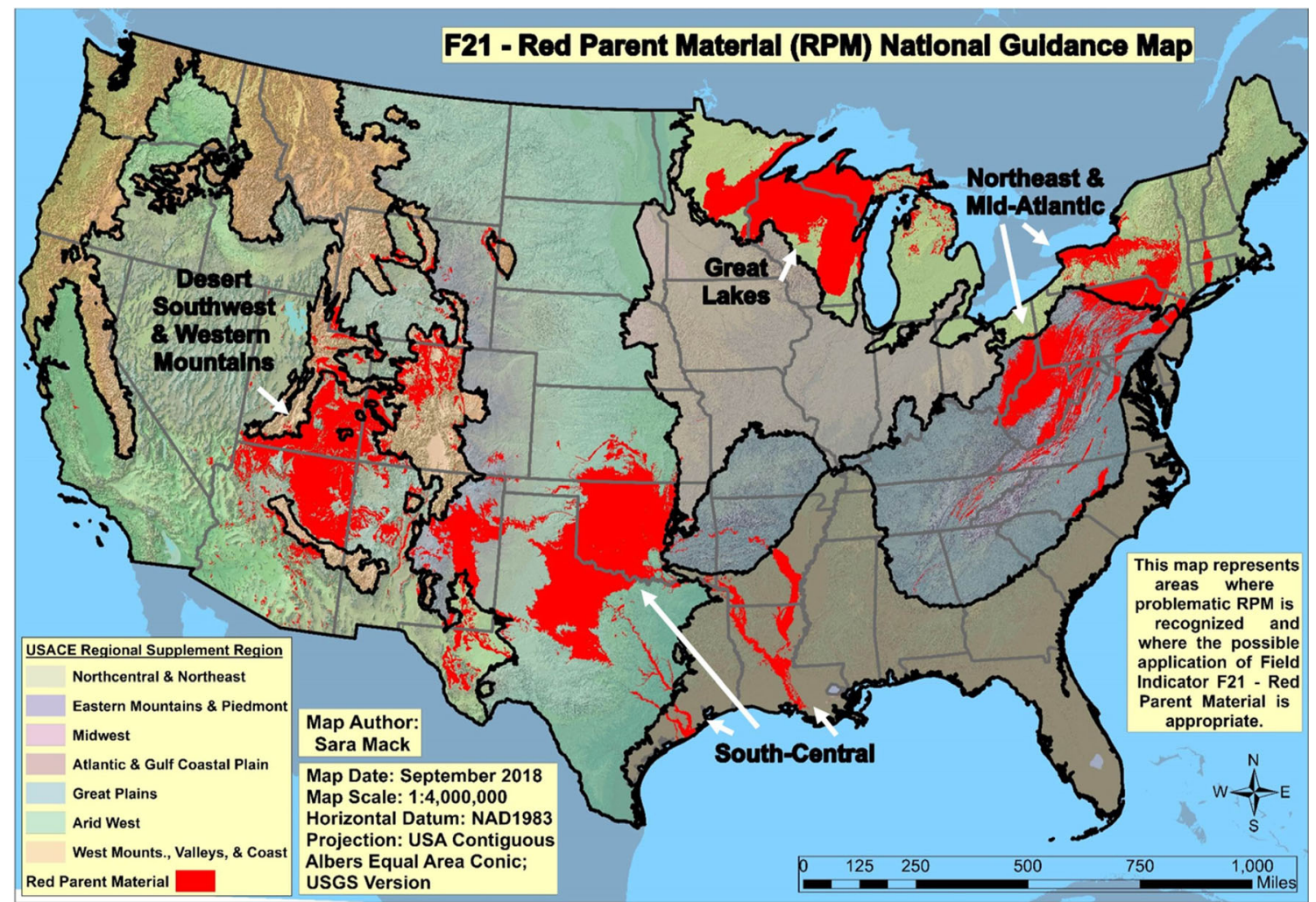

Fig. 1 National guidance map for recommended application of the F21 - Red Parent Material hydric soil field indicator in the United States. Red areas indicate locations with soils and geological formations where problematic RPM potentially occur 
Table 1 USACE regional supplement areas, LRRs, and MLRAs within the Northeast and Mid-Atlantic RPM region where application of the F21 Red Parent Material field indicator is recommended

\begin{tabular}{|c|c|c|}
\hline USACE region & Land Resource region (LRR) & Major Land Resource Area (MLRA) \\
\hline Northcentral and Northeast & $\begin{array}{l}\mathrm{L} \text { - Lake States Fruit, Truck Stop, and Dairy region } \\
\mathrm{R} \text { - Northeastern Forage and Forest Region }\end{array}$ & $\begin{array}{l}101 \text { - Ontario-Erie and Finger Lakes } \\
140 \text { - Glaciated Allegheny Plateau } \\
142 \text { - St. Lawrence-Champlain Plain } \\
144 \text { A - New England and Eastern New York Upland } \\
145 \text { - Connecticut Valley }\end{array}$ \\
\hline Eastern Mountains and Piedmont & $\mathrm{N}$ - East and Central Farming and Forest Region & $\begin{array}{l}124 \text { - Western Allegheny Plateau } \\
125 \text { - Cumberland Plateau } \\
126 \text { - Central Allegheny Plateau } \\
127 \text { - Eastern Appalachian Ridges and Valleys } \\
128 \text { - Southern Appalachian Ridges and Valleys } \\
130 \text { A - Northern Blue Ridge }\end{array}$ \\
\hline & $\begin{array}{l}\text { P - South Atlantic and Gulf Slope Cash Crops, } \\
\text { Forest, and Livestock Region } \\
\text { S - Northern Atlantic Slope Diversified Farming Region }\end{array}$ & $\begin{array}{l}136 \text { - Southern Piedmont } \\
147 \text { - Northern Appalachian Ridges and Valleys } \\
148 \text { - Northern Piedmont }\end{array}$ \\
\hline
\end{tabular}

Within the Northeast and Mid-Atlantic 76 locations contained problematic RPM (mean CCPI \pm standard deviation $=20 \pm$ 5.9), 19 locations were non-problematic (CCPI $=50 \pm 11)$ and 18 exhibited potential color change resistance (CCPI = $35 \pm 4.2$ ). Parent materials displaying problematic RPM were derived from till (31\%), alluvium (26\%), residuum $(24 \%)$, with colluvial and mixed deposits also present. The Northeast and Mid-Atlantic encompasses considerable topographic, climatic, and geologic diversity, with problematic RPM stretching across portions of thirteen U.S. states.

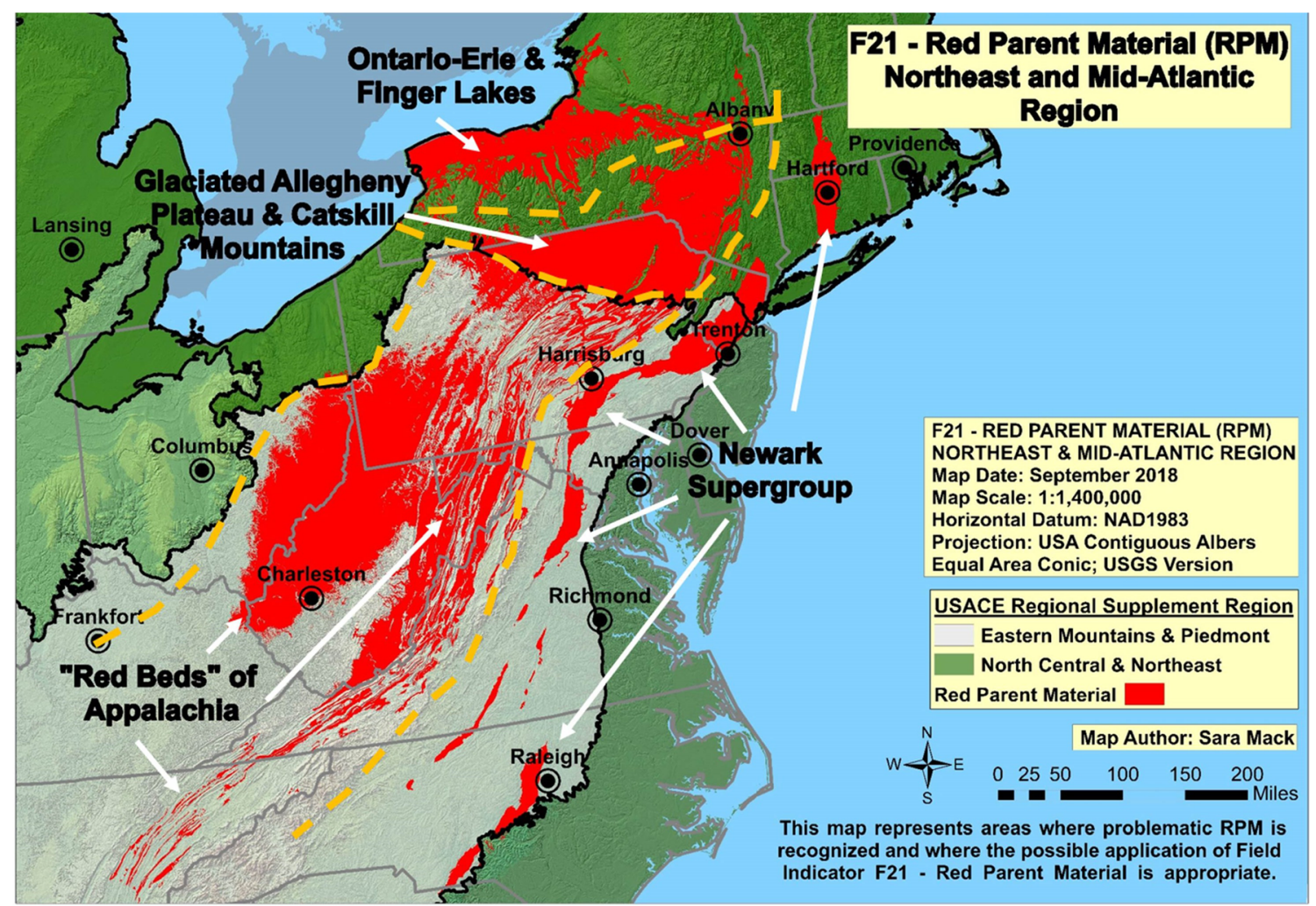

Fig. 2 Guidance map for recommended application of the F21 - Red Parent Material field indicator in the Northeast and Mid-Atlantic RPM region. Red areas indicate locations with soils and geological formations where problematic RPM potentially occur 
Generally, the geology of the problematic RPM region is differentiated between northern (USACE Northcentral and Northeast regional supplement area) and southern (USACE Eastern Mountains and Piedmont regional supplement area) portions by the southernmost extent of Pleistocene glaciations (Mack 2018; USDA-NRCS 2006). Within the Northeast and Mid-Atlantic problematic RPM region, four distinctive groups (Fig. 2) of soils and parent materials have been identified including soils derived from: 1) Paleozoic-aged, sedimentary red beds of Appalachia; 2) glacial deposits of the Glaciated Allegheny Plateau and Catskill Mountains; 3) till and (glacio)lacustrine deposits of the Ontario-Erie Plain and Finger Lakes; and 4) sedimentary rocks of the Newark Supergroup. These areas are characterized by residual and glacial soils derived from dark, red shales, siltstones, and sandstones laid down in passive continental margins during the formation of the current Appalachian mountain system (i.e. the Paleozoic "Red Beds" of Appalachia; the Glaciated Allegheny Plateau and Catskill Mountains; and the OntarioErie Plain and Finger Lakes) and in low lying basins formed during the breakup of supercontinent Pangea (i.e. the Newark Supergroup). Specific soil series and geologic formations associated with each portion of the Northeast and Mid-Atlantic problematic RPM region are provided in Tables 2, 3, 4 and 5.

\section{Great Lakes}

A total of 218 soil samples from 78 sites were analyzed for CCPI from the Great Lakes problematic RPM region. Fifty-six locations contained problematic RPM (mean CCPI \pm standard deviation $=21 \pm 6.3), 7$ locations were non-problematic $(\mathrm{CCPI}=47$ $\pm 5.3)$ and 15 exhibited potential color change resistance $(\mathrm{CCPI}=35 \pm 6.6)$. Soil materials in the Great Lakes problematic RPM region are most commonly derived from Pleistocene-aged, glacial deposits $(>67 \%)$ that stretch across portions of three U.S. states that include portions of the Northcentral and Northeast regional supplement area and two LRRs (Table 6).

In general, the Great Lakes RPM region is characterized by dark red, Wisconsinan-aged glacial deposits distributed by the advance and retreat of glacial lobes of the Laurentide ice sheet. These glacial deposits originated from red sedimentary rocks of the Superior Basin and some possible Paleozoic/Mesozoic rocks of the Michigan basin. A full reporting of the Great Lakes geologic origin is beyond the scope of the current manuscript, which focuses on linking problematic RPM distribution with soil series data to improve approaches to hydric soil identification in red soils. However, a comprehensive discussion of geologic features associated with the Great Lakes problematic RPM region is provided in Mack (2018). To
Table 2 Geological formations and soil series identified as potential problematic RPM that are associated with the Paleozoic red beds of Appalachia

\begin{tabular}{llll}
\hline Geological Formation(s) & & Soil Series & \\
\hline Bloomsburg Formation & Foreknobs Formation & Albrights & Meckesville \\
Bloomsburg Red Beds & Glenshaw Formation & Alcoa & Moshannon \\
Bluefield Formation & Greenbriar Formation & Allenwood & Neubert \\
Bluestone Formation & Greenbriar Group & Basher & Peabody \\
Casselman Formation & Greene Formation & Belpre & Pipestem \\
Catskill Formation & Hampshire Formation & Birdsboro & Raritan \\
Beaverdam Run Member & Hinton Formation & Calvin & Red Hills \\
Berry Run Member & Holston Formation & Cateache & Senecaville \\
Clarks Ferry Member & Huntley Mountain Formation & Coghill & Sensabaugh \\
Duncannon Member & Juniata Formation & Corryton & Steekee \\
Irish Valley Member & Maccrady Shale & Craigsville & Summitville \\
Long Run Member & Maccrady Formation & Gallia & Tellico \\
Packerton Member & Mauch Chunk Formation & Hackers & Ungers \\
Poplar Gap Member & Mauch Chunk Group & Hustontown & Upshur \\
Sawmill Run Member & McKenzie Formation & Leck Kill & Vandalia \\
Sherman Creek Member & Monongahela Formation & Lehew & Vandergrift \\
Towamensing Member & Monongahela Group & Linden & Vincent \\
Walcksville Member & Pennington Formation & Kedron & Watson \\
Chemung Formation & Pennington Group & Klinesville & Woodsfield \\
Clinton Group & Rose Hill Formation & Madsheep & \\
Conemaugh Formation & Slide Mountain Formation & & \\
Conemaugh Group & Washington Formation & & \\
Dunkard Group & Waynesburg Formation & & \\
\hline & & & \\
\hline
\end{tabular}


Table 3 Geological formations and soil series identified as potential problematic RPM that are associated with the Glaciated Allegheny Plateau and the Catskill Mountains area

\begin{tabular}{lll}
\hline Geological Formation(s) & Soil Series & \\
\hline Catskill Formation & Bash & Monguap \\
Beaverdam Run Member & Barbour & Morris \\
Berry Run Member & Basher & Norchip \\
Clarks Ferry Member & Cadosia & Norwich \\
Duncannon Member & Cheshire & Onteora \\
Irish Valley Member & Elka & Oquaga \\
Long Run Member & Halcott & Suny \\
Packerton Member & Hawksnest & Tor \\
Poplar Gap Member & Gretor & Trestle \\
Sawmill Run Member & Lackawanna & Tunkhannock \\
Sherman Creek Member & Lewbeach & Vly \\
Towamensing Member & Linden & Wellsboro \\
Walcksville Member & Maplecrest & Willowemoc \\
Slide Mountain Formation & Menlo & Wyoming \\
\hline
\end{tabular}

facilitate identification of problematic RPM, Fig. 3 as well as Tables 7, 8 and 9 link areas of verified problematic RPM soils with underlying geologic formations and soil series.

Areas containing problematic RPM are differentiated across the landscape based on their association with distinct tongues or lobes created during advances and retreats of the Laurentide ice sheets (Lusardi 1997). As a result, problematic RPM soils deposited by these glacial fronts, occur on a wide variety of glacial landforms (moraines, drumlins, outwash plains, lake beds). Three distinctive groups of problematic RPM soils and parent materials were identified in the Great Lakes, including soils derived from red glacial deposits associated with: the Superior Lobe; the Kewaunee formation; and the northern portion of the Michigan Basin (Fig. 3). A number of subordinate lobes further subdivide the area, with multiple episodes of

Table 4 Geological formations and soil series identified as potential problematic RPM as associated with the Ontario-Erie Plain and Finger Lakes area

\begin{tabular}{lll}
\hline Geological Formation(s) & Soil Series & \\
\hline Clinton Group & Alton & Lockport \\
Lockport Group & Appleton & Odessa \\
Medina Group & Barre & Ontario \\
Queenston Formation/Shale & Cayuga & Ovid \\
Rondout Formation & Cazenovia & Romulus \\
Salina Group & Churchville & Schoharie \\
Camillus Formation & Hilton & \\
Syracuse Formation & Lairdsville & \\
Vernon Formation & Lakemont & \\
\hline
\end{tabular}

glaciation complicating the geologic history of the area, with each glacial advance and retreat introducing new mixtures of materials including potentially problematic RPM across the landscape. As a result, the extent of potential problematic RPM in the Great Lakes (Fig. 3) must be linked with other factors prior to the identification of hydric soils (and wetlands). See the application discussion below for details on the recommended use of problematic RPM maps for additional guidance. Further, many areas exhibit problematic RPM at depths below a mantle of recently deposited soil materials that may or may not contain materials resistant to color change. The authors observed this during several field site visits in which the problematic RPM (and field indicator F21 - RPM) was encountered at depths $\geq 20 \mathrm{~cm}$ below the soil surface. Accumulations of organic materials (i.e. histic epipedons) or other nonproblematic soils that rapidly develop redoximorphic features may also overlay problematic RPM deposits. In these cases, other field indicators of hydric soils may be useful in delineating hydric soils and associated wetland features.

\section{South-Central}

A total of 300 soil samples from 148 sites underwent CCPI from the South-Central problematic RPM region, resulting in identification of problematic RPM in 28 MLRAs across eight LRRs. Of those samples, $27 \%$ exhibited problematic RPM characteristics $(\mathrm{CCPI}=26 \pm 4.9), 29 \%$ displayed some color change resistance (CCPI $=36 \pm 4.6$ ), and $43 \%$ were nonproblematic $(\mathrm{CCPI}=58 \pm 19)$. Where present, problematic RPM mostly occurred in soils derived from alluvial and residual parent materials.

Problematic RPM predominantly occurred within the USACE Great Plains and Atlantic and Gulf Coast Plain regional supplement areas, with small areas also found in the Midwest and the Eastern Mountains and Piedmont areas (Fig. 4; Table 10). Problematic RPM occurred across parts of central Texas, Oklahoma, and southern Kansas. Additionally, major rivers and tributary networks rivers transported problematic RPM materials into the alluvial valleys of Arkansas and Louisiana. The South Central problematic RPM region is characterized mostly by residual and alluvial soils derived from Permian-aged bedrock of the Great Plains (i.e. the Central Red Bed Plains), and recent alluvial deposits of the Red, Brazos, and other rivers in southern parts of the Coastal Plain physiographic province (i.e. Central Red Bed Plains Alluvium). Problematic RPMs in the SouthCentral group vary west to east as conditions shift from the drier, bedrock-controlled portions of the Great Plains to the wetter, thick alluvial deposits overlying the Coastal Plain.

Problematic RPM in the Great Plains typically occurs as Permian-aged, red bed formations found on gently rolling plains and prairies dissected by current and ancient stream terraces in the north, and more eroded plateau areas with 
Table 5 Geological formations and soil series identified as potential problematic RPM that are associated with basins of the Newark Supergroup

\begin{tabular}{|c|c|c|c|}
\hline \multirow{2}{*}{$\frac{\operatorname{Basin}(\mathrm{s})}{\text { Harford, Deerfield, Northfield }}$} & \multirow{2}{*}{$\begin{array}{l}\text { Geological Formation(s) } \\
\text { East Berlin Formation } \\
\text { Mount Toby Formation } \\
\text { New Haven Arkose } \\
\text { Portland Arkose } \\
\text { Shuttle Meadow Formation } \\
\text { Sugarloaf Formation } \\
\text { Turner Falls Sandstone }\end{array}$} & \multicolumn{2}{|l|}{ Soil Series } \\
\hline & & $\begin{array}{l}\text { Bash } \\
\text { Berlin } \\
\text { Branford } \\
\text { Brownsburg } \\
\text { Cheshire } \\
\text { Ellington } \\
\text { Harford } \\
\text { Holyoke }\end{array}$ & $\begin{array}{l}\text { Ludlow } \\
\text { Manchester } \\
\text { Menlo } \\
\text { Penwood } \\
\text { Watchaug } \\
\text { Wethersfield } \\
\text { Wilbraham } \\
\text { Yalesville }\end{array}$ \\
\hline Newark & $\begin{array}{l}\text { Boonton Formation } \\
\text { Brunswick Formation } \\
\text { Feltville Formation } \\
\text { Hammer Creek Formation } \\
\text { Lockatong Formation } \\
\text { Passaic Formation } \\
\text { Raritan Formation } \\
\text { Stockton Formation } \\
\text { Towaco Formation }\end{array}$ & $\begin{array}{l}\text { Abbottstown } \\
\text { Arendtsville } \\
\text { Athol } \\
\text { Bermudian } \\
\text { Birdsboro } \\
\text { Boonton } \\
\text { Bowmansville } \\
\text { Brecknock } \\
\text { Bucks }\end{array}$ & $\begin{array}{l}\text { Knauers } \\
\text { Lamington } \\
\text { Lansdale } \\
\text { Landsdowne } \\
\text { Lawrenceville } \\
\text { Lewisberry } \\
\text { Lucketts } \\
\text { Morven } \\
\text { Nixon }\end{array}$ \\
\hline Gettysburg & $\begin{array}{l}\text { Gettyburg Conglomerate } \\
\text { Gettysburg Formation } \\
\quad \text { Heidlersburg Member } \\
\text { Gettysburg Shale } \\
\text { Hammer Creek Conglomerate } \\
\text { Hammer Creek Formation } \\
\text { New Oxford Conglomerate } \\
\text { New Oxford Formation }\end{array}$ & $\begin{array}{l}\text { Buckingham } \\
\text { Chalfont } \\
\text { Croton } \\
\text { Doylestown } \\
\text { Dunellen } \\
\text { Exway } \\
\text { Greenbelt } \\
\text { Haledon } \\
\text { Joanna } \\
\text { Klinesville }\end{array}$ & $\begin{array}{l}\text { Norton } \\
\text { Pascask } \\
\text { Penn } \\
\text { Quakertown } \\
\text { Raritan } \\
\text { Readington } \\
\text { Reaville } \\
\text { Rowland } \\
\text { Springwood }\end{array}$ \\
\hline Culpeper, Barboursville, Scottsville & $\begin{array}{l}\text { Newark Supergroup - conglomerates, } \\
\text { sandstones, siltstones, shales, mudstones }\end{array}$ & $\begin{array}{l}\text { Aden } \\
\text { Albano } \\
\text { Arcola } \\
\text { Ashburn } \\
\text { Brentsville } \\
\text { Calverton } \\
\text { Catlett } \\
\text { Clover } \\
\text { Dulles } \\
\text { Kelly }\end{array}$ & $\begin{array}{l}\text { Leedsville } \\
\text { Manassas } \\
\text { Nestoria } \\
\text { Oatlands } \\
\text { Ott } \\
\text { Panorama } \\
\text { Rapidan } \\
\text { Sudley } \\
\text { Sycoline } \\
\text { Totier }\end{array}$ \\
\hline $\begin{array}{l}\text { Crowburg, Wadesboro, Ellerbe, Sanford, } \\
\text { Durham, Davie County, Dan River, } \\
\text { Danville, Scottsburg, Randolph, Roanoke } \\
\text { Creek, Briery Creek, Farmville }\end{array}$ & $\begin{array}{l}\text { Chatham Group } \\
\text { Cow Branch Formation } \\
\text { Cumnock Formation } \\
\text { Dan River Group } \\
\text { Pekin Formation } \\
\text { Pine Hall Formation } \\
\text { Sanford Formation } \\
\text { Stoneville Formation }\end{array}$ & $\begin{array}{l}\text { Ayersville } \\
\text { Belews Lake } \\
\text { Brickhaven } \\
\text { Carbonton } \\
\text { Claycreek } \\
\text { Creedmoor } \\
\text { Easthamlet } \\
\text { Granville } \\
\text { Hallison } \\
\text { Hasbrouck } \\
\text { Hornsboro } \\
\text { Lackstown } \\
\text { Leaksville } \\
\text { Mayodan }\end{array}$ & $\begin{array}{l}\text { Meadows } \\
\text { Mooshaunee } \\
\text { Peakin } \\
\text { Pinkston } \\
\text { Pinoka } \\
\text { Polkton } \\
\text { Sheva } \\
\text { Spray } \\
\text { Stoneville } \\
\text { Straightstone } \\
\text { Wadesboro } \\
\text { Warminster } \\
\text { White Store } \\
\text { Wolftrap }\end{array}$ \\
\hline
\end{tabular}

deeply entrenched streams and rivers in the south. The RPM soils in these areas are often shallow, overlying the red-colored bedrock. In the Atlantic Gulf Coast Plain, RPM soils are derived from red-colored alluvial deposits of major river systems that drain the Permian red beds described above. These alluvial soils occur on terraces, floodplains, lowlands, and deltas along major river systems. Minor RPM areas are also possible in small portions of the USACE Midwest and Eastern
Mountains regional supplement areas, where RPM is associated with river systems transporting problematic RPM materials.

Although problematic RPM and their associated soils are extensive in the portions of the South Central United States, much of the area exhibits an ustic soil moisture regime, limiting the extent of hydric soils. Nevertheless, Permian red beds provide the source rocks of RPM soils stretching across several states through alluvial transport. As a result, the F21 - 
Table 6 USACE regional supplement areas, LRRs, and MLRAs within the Great Lakes RPM region where application of the F21 - Red Parent Material hydric soil field indicator is recommended

\begin{tabular}{|c|c|c|}
\hline USACE region & Land Resource Region (LRR) & Major Land Resource Area (MLRA) \\
\hline Northcentral and Northeast & $\mathrm{K}$ - Northern Lake States Forest and Forage Region & $\begin{array}{l}\text { 57 - Northern Minnesota Gray Drift } \\
\text { 88 - Northern Minnesota Glacial Lake Basins } \\
\text { 89 - Wisconsin Central Sands } \\
\text { 90A - Wisconsin and Minnesota Thin Loess and Till, Northern Part } \\
\text { 90B - Wisconsin and Minnesota Thin Loess and Till, Southern Part } \\
\text { 91 A - Central Minnesota Sandy Outwash } \\
\text { 91B - Wisconsin and Minnesota Sandy Outwash } \\
\text { 92 - Superior Lake Plain } \\
\text { 93A - Superior Stony and Rocky Loamy Plains and Hills, Western Part } \\
\text { 93B - Superior Stony and Rocky Loamy Plains and Hills, Eastern Part } \\
\text { 94A - Northern Michigan and Wisconsin Sandy Drift } \\
\text { 94B - Michigan Eastern Upper Peninsula Sandy Drift } \\
\text { 94C - Michigan Northern Lower Peninsula Sandy Drift } \\
\text { 94D - Northern Highland Sandy Drift } \\
\text { 95A - Northeastern Wisconsin Drift Plain } \\
\text { 95B - Southern Wisconsin and Northern Illinois Drift Plain } \\
\text { 96 - Western Michigan Fruit Belt } \\
\text { 98 - Southern Michigan and Northern Indiana Drift Plain } \\
\text { 99 - Erie-Huron Lake Plain }\end{array}$ \\
\hline
\end{tabular}

Red Parent Material may be useful in identifying hydric soils in landscape positions where water accumulates and wetlands are likely to occur as well as in aquic portions of southeastern Texas and Louisiana where wetlands are more common (U.S. Army Corps of Engineers 2010a). To facilitate identification of problematic RPM in a field setting, Tables 11 and 12 link areas of verified problematic RPM soils with underlying geologic formations and soil series.

\section{Desert Southwest and Western Mountains}

A total of 237 soil samples from 97 sites underwent analysis for CCPI from the Desert Southwest and Western Mountains problematic RPM region. Residual deposits accounted for the majority of parent materials associated with problematic RPM soils (>55\%), with alluvial deposits $(30 \%)$ and mixed source materials also present. Problematic RPM soil CCPI results were significantly lower $(\mathrm{CCPI}=19 \pm 5.6)$ than potential $(\mathrm{CCPI}=34 \pm 2.9 ; p<0.001)$ and non-problematic soils $(\mathrm{CCPI}=49 \pm 10 ; \mathrm{p}<0.001)$. As a result, problematic RPM has been identified for recommended use of the F21 - Red Parent Material hydric soil field indicator in 26 MLRAs of five LRRs. These mostly occur within the USACE Arid West and the Western Mountains, Valleys, and Coast regional supplement areas, with minor areas also occurring in portions of the Great Plains regional supplement area (Table 13; Fig. 5).

The Desert Southwest and Western Mountains problematic RPM region encompasses portions of Arizona, Colorado, New Mexico, Texas, South Dakota, Utah, and Wyoming. The problematic RPM in this region occurs across six vastly different physiographic provinces: the Colorado Plateaus,
Middle (Central) Rocky Mountains, Southern Rocky Mountains, Wyoming Basin, Basin and Range (Mexican Highland and Sacramento sections), and portions of the Great Plains (Black Hills, Pecos Valley, and Edwards Plateau sections). Soils within the Desert Southwest and Western Mountains problematic RPM region are characterized by residual, colluvial, and alluvial soils derived from dark, red Paleozoic and Mesozoic-aged rocks uplifted and preserved in the regions mountain ranges (i.e. the Middle and Southern Rockies, Black Hills, Arizona and New Mexico Mountains, Wasatch and Uinta Mountains) and the various plateaus, canyons, and gorges (i.e. the Colorado Plateau and Pecos River Valley) associated with those features. Despite the variability in soils observed in area, the terrestrial red beds that produced problematic RPM soils share similar geological origin related to the erosion and deposition of the Ancestral Rocky Mountains (Table 14; Branson 1927; Reeside 1929; Baker et al. 1947; Pipiringos 1968; Lucas et al. 1993; Lucas and Anderson 1998).

The following groups of problematic RPM and their associated soils where the F21 - Red Parent Material field indicator may be applied include: 1) portions of the Western Mountains, Valleys and Coasts regional supplement area and surrounding foothills; 2) the Colorado Plateaus physiographic province (i.e., the Four Corners region); and 3) the Pecos River Valley (Mack 2018). Problematic RPM associated with the Western Mountains, Valleys, and Coast regional supplement area and surrounding foothills (U.S. Army Corps of Engineers 2010b) includes portions of the central and southern Rockies, the Black Hills, the Arizona and New Mexico mountains, and the Wasatch and Uinta mountains (Fig. 5). As noted elsewhere, understanding where red bed formations and 
Table 7 Geological formations and soil series identified as potential problematic RPM associated with the Superior Lobe

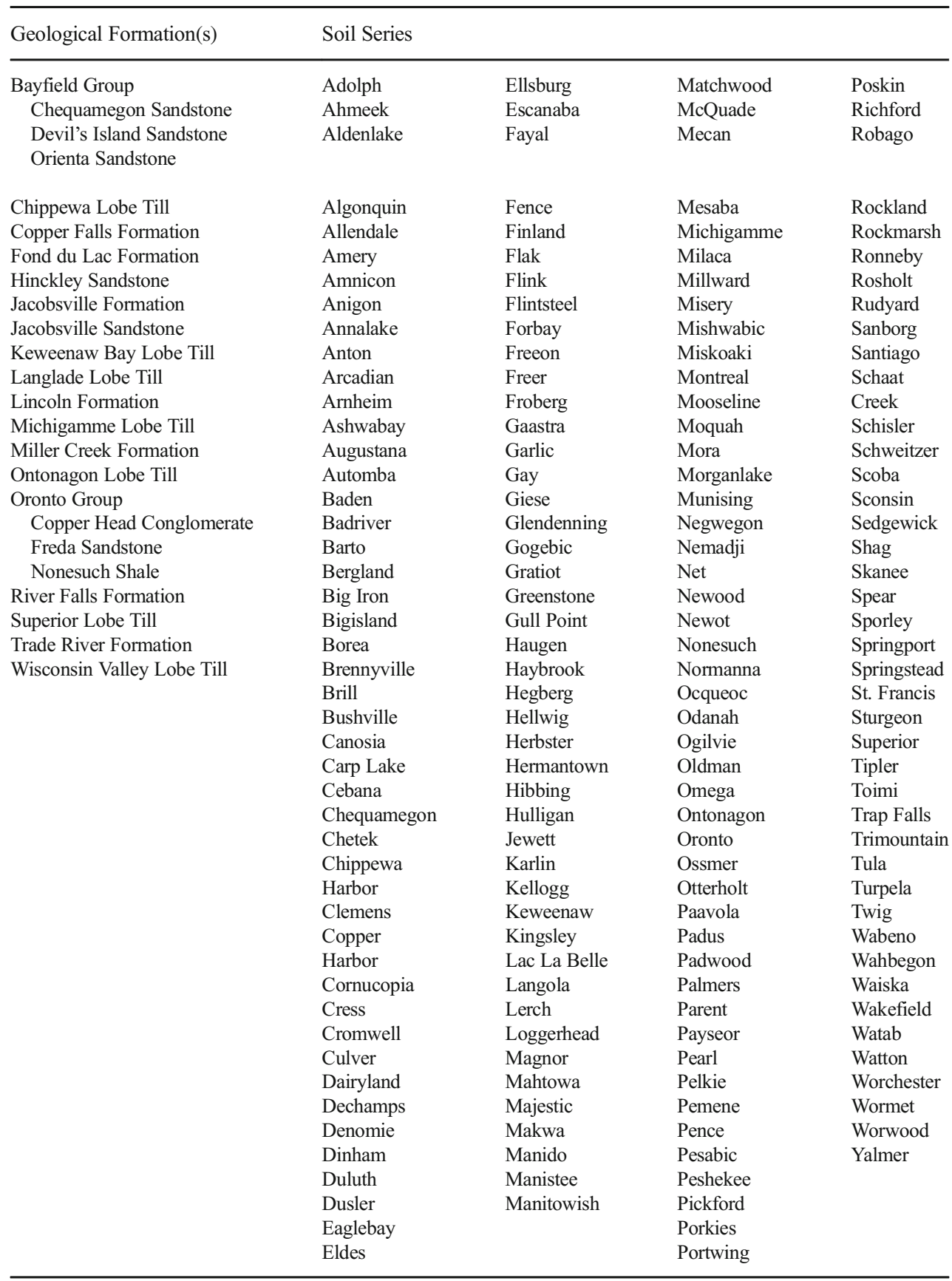

associated soil series (Table 15, 16 and 17) are located will help identify hydric soils derived from problematic RPM soils in these areas. While problematic RPM and their associated soils are extensive, the expanse of ustic and aridic soil moisture regimes likely limits the extent of hydric soils. However, the F21 - Red Parent Material may be useful in identifying hydric soils where water accumulates and wetlands are likely to occur across the landscape including riverine, depressional, and groundwater discharge landscape positions.

Interestingly, the Permian red beds of the Pecos River Valley are lithologically correlated with strata confirmed in the South-Central problematic RPM region discussed previously, while the Mesozoic red beds are lithologically correlated to those that occur in the Colorado Plateaus and Rocky Mountain systems. Like the red beds of the Central Red Beds Plains, the rock sequences known to contain red beds also grade into sequences dominated by gray, marinecarbonate rocks that are not recognized as problematic RPM. A variety of river systems drain areas characterized by problematic RPM. Therefore, alluvial deposits may be comprised of (or contain) problematic RPM soils. Furthermore, the headwater of the Pecos, Canadian and Cimarron rivers flow across 
Table 8 Geological formations and soil series identified as potential problematic RPM that are associated with the Kewaunee formation

\begin{tabular}{|c|c|c|c|}
\hline \multirow{2}{*}{$\begin{array}{l}\text { Geological Formation(s) } \\
\text { Bayfield Group }\end{array}$} & \multicolumn{3}{|l|}{ Soil Series } \\
\hline & Angelica & Moquah & Tipler \\
\hline Chequamegon Sandstone & Banat & Mosel & Wabeno \\
\hline Devil's Island Sandstone & Bonduel & Moshawquit & Waymor \\
\hline Orienta Sandstone & Borth & Nadeau & Winneconne \\
\hline Fond du Lac Formation & Briggsville & Omena & Worchester \\
\hline Green Bay Lobe Till & Cress & Omro & Wormet \\
\hline Hinckley Sandstone & Cunard & Onaway & Wyocena \\
\hline Holy Hill Formation & Elderon & Oshkosh & Zittau \\
\hline Horicon Member & Emmert & Ossineke & Zurich \\
\hline Liberty Grove Member & Escanaba & Pearl & \\
\hline Kewaunee Formation & Fairport & Pecore & \\
\hline Branch River Member & Fence & Peebles & \\
\hline Chilton Member & Frechette & Pelkie & \\
\hline Florence Member & Gaastra & Pemene & \\
\hline Glenmore Member & Hortonville & Perote & \\
\hline Kirby Lake Member & Kaukauna & Peshekee & \\
\hline Middle Inlet Member & Kennan & Peshtigo & \\
\hline Ozaukee Member & Keshena & Poy & \\
\hline Silver Cliff Member & Kewaunee & Poygan & \\
\hline Two Rivers Member & Keweenaw & Rabe & \\
\hline Valders Member & Kiva & Richford & \\
\hline Jacobsville Formation & Kolberg & Rosholt & \\
\hline Jacobsville Sandstone & Longrie & Shawano & \\
\hline Oronto Group & Manawa & Solona & \\
\hline Copper Head Conglomerate & Manistee & Stambaugh & \\
\hline Freda Sandstone & Mecan & Symco & \\
\hline Nonesuch Shale & Montello & Tilleda & \\
\hline
\end{tabular}

red beds identified as problematic RPM in the Upper Pecos River Valley providing alluvial source materials for problematic RPM soils as they proceed east and south (Mack 2018).

\section{Application of F21 - Red Parent Material for Hydric Soil and Wetland Delineation}

The RPM guidance maps, supplemental information on associated geologic features, and soil series lists are designed to aid practitioners in overcoming obstacles in accurately identifying hydric soils derived from problematic RPM. Maps and tables link soil series, geological formations, and parent materials containing problematic RPM with USACE regional supplement areas, LRRs, and MLRAs, allowing users to rapidly identify potential problematic RPM soils through a variety of pathways. For example, problematic RPM can be identified based upon information regarding either soil survey data, soil series identification or geologic formation information
Table 9 Geological formations and soil series identified as potential problematic RPM that are associated with the Michigan Basin

\begin{tabular}{lll}
\hline Geological Formation(s) & Soil Series & \\
\hline Bayfield Group & Algonquin & Morganlake \\
Chequamegon Sandstone & Allendale & Nadeau \\
Devil's Island Sandstone & Angelica & Negwegon \\
Orienta Sandstone & Annalake & Nunica \\
Fond du Lac Formation & Bergland & Ocqueoc \\
Hinckley Sandstone & Biscuit & Oldman \\
Ionia Formation & Bonduel & Omena \\
Jacobsville Formation & Cunard & Onaway \\
Jacobsville Sandstone & Engadine & Ontonagon \\
Jurassic Red Beds & Fairport & Ossineke \\
Oronto Group & Fence & Pelkie \\
Copper Head Conglomerate & Fibre & Pickford \\
Freda Sandstone & Gaastra & Poy \\
Nonesuch Shale & Gay & Rudyard \\
Queenston Formation & Graveraet & Solona \\
Salina Group & Karlin & Sporley \\
& Kellogg & Springport \\
& Kiva & Superior \\
& Longrie & Waiska \\
& Manistee & \\
\hline & & \\
& &
\end{tabular}

within a given location (e.g., USACE Atlantic Gulf Coastal Plain region; LRR T; MLRA 152A).

Notably, the guidance maps developed encompass all areas potentially containing problematic RPM, including both wetland and upland areas. The provided tables are not limited to soils which appear on the hydric soils list or soil series with poorly and very poorly drained designations. As a result, identification of hydric soils requires both the presence of problematic RPM as determined by the maps, geologies, and soil series lists herein, and the conditions outlined in the F21 - Red Parent Material hydric soil field indicator. Further, for an area to be identified as a wetland, areas exhibiting problematic RPM must also display indicators of wetland hydrology and hydrophytic vegetation as required by the procedures outlined in the USACE wetland delineation manual and associated regional supplements. Based on the findings in the current study, a proposal will be made to the National Technical Committee for Hydric Soils to revise the guidance for F21Red Parent Material application. The revisions will apply the technical criteria of the hydric soil indicator as written, but require either the application of CCPI data or the occurrence of potential problematic RPM soils within one of the problematic RPM regions described herein. This approach will promote the proper application of the F21 - Red Parent Material hydric soil field indicator without requiring laboratory data collection for individual project areas. Additional site specific 


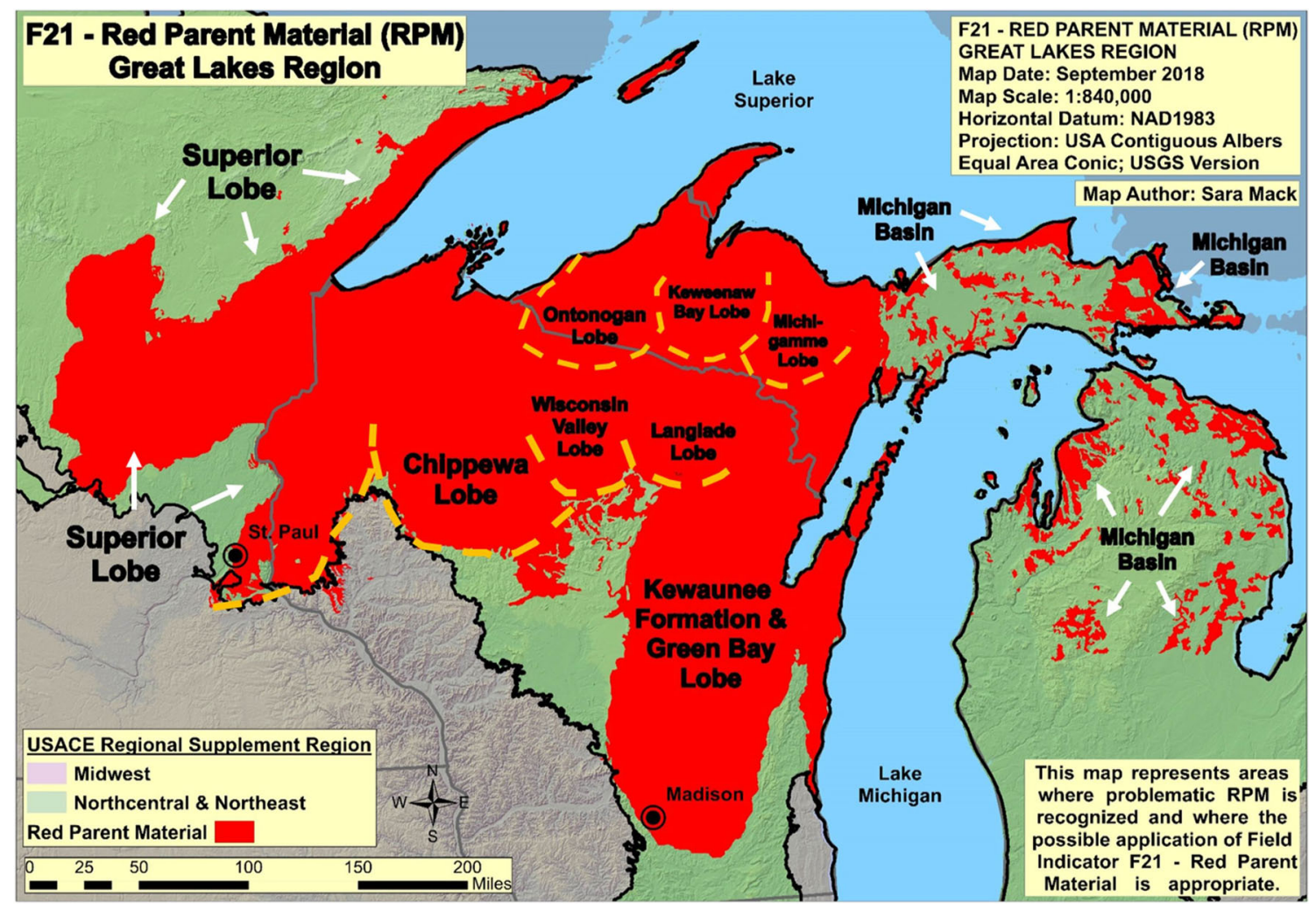

Fig. 3 Guidance map for recommended application of the F21 - Red Parent Material field indicator in the Great Lakes RPM region. Red areas indicate locations with soils and geological formations where problematic RPM are possible

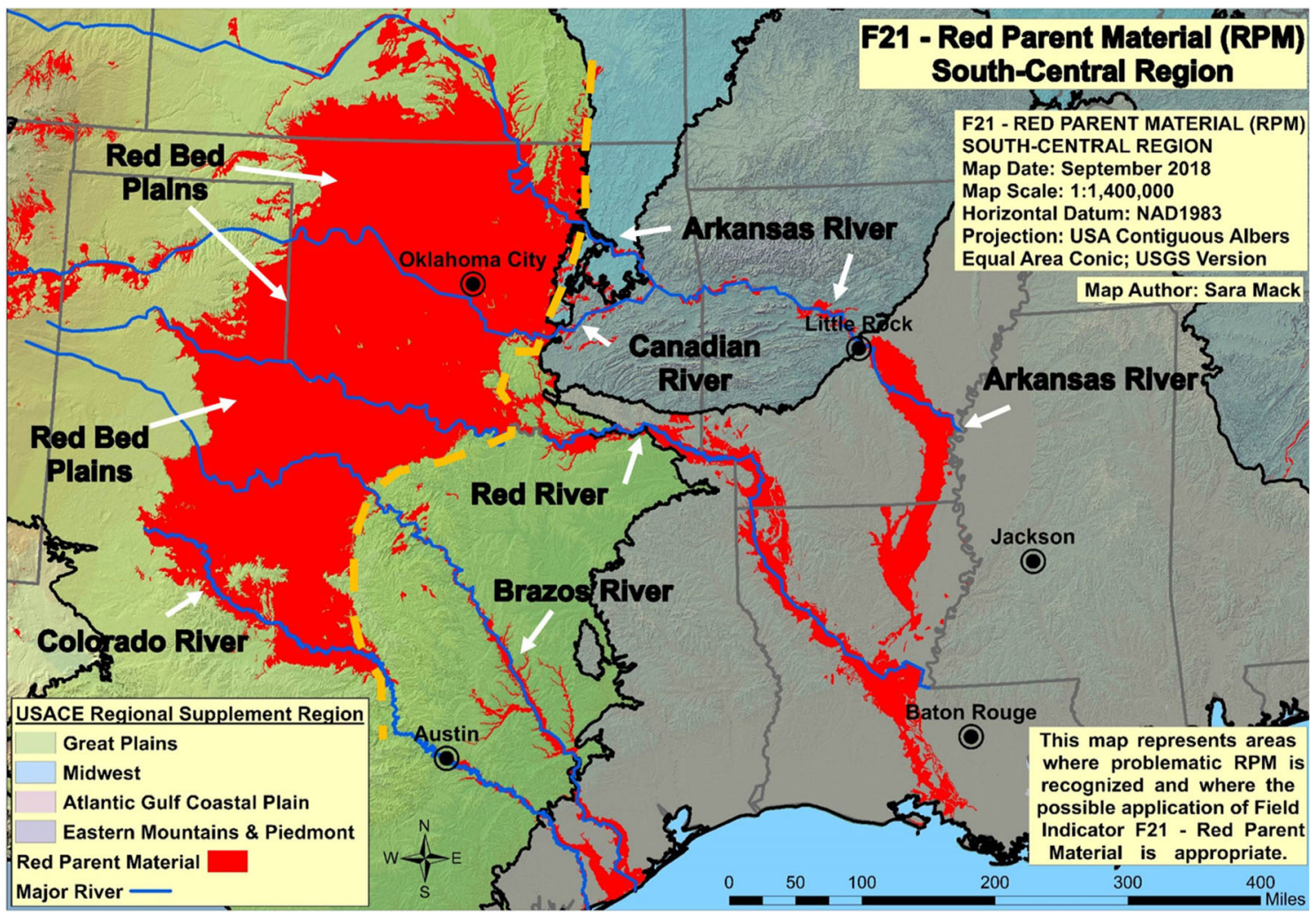

Fig. 4 Guidance map for recommended application of the F21 - Red Parent Material field indicator in the South-Central RPM region. Red areas indicate locations with soils and geological formations where problematic RPM are possible 
Table 10 USACE regional supplement areas, LRRs, and MLRAs within the South-Central RPM region where application of the F21 - Red Parent Material hydric soil field indicator is recommended

\begin{tabular}{|c|c|c|}
\hline USACE region & Land Resource Region (LRR) & Major Land Resource Area (MLRA) \\
\hline \multirow[t]{4}{*}{ Great Plains and Midwest } & H - Central Great Plains Winter Wheat and Range Region & $\begin{array}{l}\text { 78A - Rolling Limestone Prairie } \\
\text { 78B - Central Rolling Red Plains, } \\
\text { 78C - Central Rolling Red Plains, } \\
\text { 80A - Central Rolling Red Prairies } \\
\text { 80B - Texas North-Central Prairies }\end{array}$ \\
\hline & I - Southwest Plateaus and Plains Range and Cotton Region & $\begin{array}{l}\text { 81B - Edwards Plateau, Central Part } \\
\text { 81C - Edwards Plateau, Eastern Part } \\
\text { 82A - Texas Central Basin }\end{array}$ \\
\hline & $\mathrm{J}$ - Southwestern Prairies Cotton and Forage Region & $\begin{array}{l}\text { 82B - Wichita Mountains } \\
\text { 84A - North Cross Timbers } \\
\text { 84B - West Cross Timbers } \\
\text { 84C - East Cross Timbers } \\
\text { 85 - Grand Prairie } \\
\text { 86A\&B - Texas Blackland Prairie } \\
\text { 87A\&B - Texas Claypan Area }\end{array}$ \\
\hline & M - Central Feed Grains and Livestock Region & 112 - Cherokee Prairies \\
\hline Eastern Mountains and Piedmont & $\mathrm{N}$ - East and Central Farming and Forest Region & $\begin{array}{l}\text { 118A - Arkansas Valley and Ridges, Eastern Part } \\
\text { 118B - Arkansas Valley and Ridges, Western Part }\end{array}$ \\
\hline Atlantic and Gulf Coast Plain & O - Mississippi Delta Cotton and Feed Grains Region & $\begin{array}{l}\text { 131A - Southern Mississippi River Alluvium } \\
\text { 131B - Arkansas River Alluvium } \\
\text { 131C - Red River Alluvium }\end{array}$ \\
\hline Atlantic and Gulf Coast Plain & $\begin{array}{l}\text { P - South Atlantic and Gulf Slope Cash Crops, Forest, } \\
\text { and Livestock Region } \\
\mathrm{T}-\text { Atlantic and Gulf Coast Lowland Forest and Crop Region }\end{array}$ & $\begin{array}{l}\text { 133B - Western Coastal Plain } \\
\text { 134 - Southern Mississippi Valley Loess } \\
\text { 135B - Cretaceous Western Coastal Plain } \\
\text { 150A - Gulf Coast Prairies } \\
\text { 150B - Gulf Coast Saline Prairies }\end{array}$ \\
\hline
\end{tabular}

Table 11 Geological formations and soil series identified as potential problematic RPM within the Central Red Bed Plains

\begin{tabular}{|c|c|c|c|c|c|}
\hline \multicolumn{2}{|l|}{ Geological Formation(s) } & \multicolumn{4}{|l|}{ Soil Series } \\
\hline Admiral Formation & Marlow Formation & Altus & Foard & Lugert & Roark \\
\hline Archer City Formation & Doe Creek Lentil & Arnett & Frankirk & Lutie & Ruella \\
\hline \multirow[t]{2}{*}{ Bear Mountain Formation } & \multirow[t]{2}{*}{ Verden Sandstone Lentil } & Ashport & Gaddy & Madge & Rups \\
\hline & & Aspermont & Gageby & Mangum & Sagerton \\
\hline Big Basin Formation & Moran Formation & Aydelotte & Gracemont & Masham & Selman \\
\hline Bison Formation & Nippewalla Group & Beckman & Gracemore & McKnight & Shrewder \\
\hline Blaine Formation & Nocona Formation & Bethany & Grainola & McLain & Southside \\
\hline Elm Fork Member & Petrolia Formation & Binger & Grandfield & Milan & Spikebox \\
\hline Van Vacter Member & Post Oak Conglomerate & Bukreek & Grant & Miles & St. Paul \\
\hline Cedar Hill Sandstone & Post Oak Formation & Burford & Hardeman & Miller & Stamford \\
\hline Chickasha Formation & Post Oak Sandstone & Burson & Harrah & Minco & Stoneburg \\
\hline Clear Fork Formation & Pueblo Formation & Callahan & Hayfork & Mulhall & Teller \\
\hline Clear Fork Group & Purcell Sandstone & Canadian & Heman & Nash & Tillman \\
\hline Cloud Chief Formation & Quartermaster Formation & Carey & Hinkle & Nashville & Tilvern \\
\hline Dockum Group & Rush Springs Formation & Chickasha & Hollister & Newalla & Tipton \\
\hline Dog Creek Shale & Weatherford Gypsum Bed & Clairemont & Huska & Nipsum & Treadway \\
\hline Doxey Formation & & Clearfork & Ironmound & Noble & Vernon \\
\hline Doxey Shale & Salt Plains Formation & Cobb & Jamash & Norge & Vinson \\
\hline Duncan Sandstone & San Angelo Formation & Colorado & Jaywi & Oakley & Wakita \\
\hline El Reno Group & San Angelo Sandstone & Cordell & Jester & Obaro & Waurika \\
\hline Elk City Sandstone & Santa Anna Branch Shale & Cornick & Jolly & Oscar & Westola \\
\hline Elm Creek Formation & Sumner Group & Cosh & Kamay & Ozark & Westill \\
\hline Fairmont Shale & Talpa Formation & Darsil & Kingco & Paducah & Westview \\
\hline Flowerpot Shale & Valera Formation & Darnell & Kingfisher & Pawhuska & Wetbeth \\
\hline Garber Sandstone & Waggoner Ranch Formation & Decobb & Kirkland & Piedmont & Weymouth \\
\hline Grape Creek Formation & & Deepwood & Knoco & Pond Creek & Wheatwood \\
\hline Guadalupian Series & Wellington Formation & Dill & Konawa & Port & Wichita \\
\hline Hennessey Group & Whitehorse Formation & Dodson & La Casa & Pulaski & Winters \\
\hline Jagger Bend Formation & Whitehorse Group & Drummond & Lawrie & Quanah & Wisby \\
\hline Kingman Formation & Wichita Group & Duke & Lawton & Quinlan & Woodward \\
\hline Kingman Siltstone & Wolfcampian Series & Enterprise & Lebron & Reinach & Yahola \\
\hline Leuders Formation & & Easpur & Lela & Renfrow & Yomont \\
\hline & & Ezell & Littleaxe & Renthin & Zaneis \\
\hline & & Farry & Lovedale & Retrop & Zellmont \\
\hline
\end{tabular}


Table 12 Geological formations and soil series identified as potential problematic RPM associated with alluvial deposits dissecting the Central Red Bed Plains

\begin{tabular}{|c|c|c|c|c|c|}
\hline \multirow{2}{*}{$\frac{\text { Geological Formation(s) }}{\text { Arkansas River Alluvium }}$} & \multicolumn{5}{|l|}{ Soil Series } \\
\hline & Addielou & Dougherty & Keo & Muldrow & Severn \\
\hline Canadian River Alluvium & Armistead & Forbing & Kiomatia & Necessity & Ships \\
\hline C. & Bastrop & Gaddy & Konawa & Norwood & Solier \\
\hline Cimarron River Alluvium & Belk & Gallion & Larton & Okay & Sonnier \\
\hline \multirow[t]{10}{*}{ Red River Alluvium } & Billyhaw & Garton & Latanier & Oklared & Sterlington \\
\hline & Bistineau & Glenwild & Lebeau & Perry & Stidham \\
\hline & Bossier & Goodwill & Lela & Portland & Ustibuck \\
\hline & Buxin & Gore & Liddieville & Porum & Wabbaseka \\
\hline & Caplis & Hebert & McGehee & Redlake & Waskom \\
\hline & Caspiana & Hicota & McKamie & Redport & Weswood \\
\hline & Choska & Idabel & Mer Rouge & Rilla & Whakana \\
\hline & Coushatta & Idee & Miller & Rodessa & Yahola \\
\hline & Dardanelle & Kamie & Moreland & Roebuck & Yorktown \\
\hline & Desha & Karma & Morse & Roxana & \\
\hline Brazos River Alluvium & Apalo & Clemville & Highbank & Oklared & Sumpf \\
\hline \multirow{8}{*}{ Colorado River Alluvium } & Aquilla & Coarsewood & Hornsby & Paluxy & Surfside \\
\hline & Asa & Colorado & Kopperl & Pledger & Velasco \\
\hline & Bastrop & Decordova & Mangum & Rabbs & Westola \\
\hline & Belk & Gad & Miles & Roetex & Wheatwood \\
\hline & Bergstrom & Gaddy & Miller & Sagerton & Weswood \\
\hline & Brazoria & Gageby & Minwells & Ships & Winters \\
\hline & Churnabog & Gause & Mohat & Smithville & Yahola \\
\hline & Clearfork & Gholson & Norwood & & \\
\hline
\end{tabular}

CCPI data can be collected if problematic RPM soil occurs outside of the current guidance maps, further expanding the available dataset.
The following steps are recommended when users encounter soils containing potential problematic RPM: 1) Determine if the soil occurs in association with a series or geologic

Table 13 USACE regional supplement areas, LRRs, and MLRAs within the Desert Southwest and Western Mountains RPM region where application of the F21 - Red Parent Material hydric soil field indicator is recommended

\begin{tabular}{|c|c|c|}
\hline USACE region & Land Resource Region (LRR) & Major Land Resource Area (MLRA) \\
\hline Arid West & D - Western and Irrigated Region & $\begin{array}{l}32 \text { - Northern Intermountain Basins } \\
34 \mathrm{~A} \text { - Cool Central Desertic Basins and Plateaus } \\
\text { 34B - Warm Central Desertic Basins and Plateaus } \\
35 \text { - Colorado Plateau } \\
36 \text { - Southwest Plateaus, Mesas, and Foothills } \\
38 \text { - Mogollon Transition } \\
41 \text { - Southeastern Arizona Basin and } \\
\text { Range* } \\
42 \text { - Southern Desertic Basins, Plains, and Mountains }\end{array}$ \\
\hline \multirow[t]{3}{*}{ Great Plains } & G - Western Great Plains and Irrigated Region & $\begin{array}{l}61 \text { - Black Hills Foot Slopes } \\
70 \mathrm{~A} \text { - Canadian River Plains and Valleys } \\
\text { 70B - Upper Pecos River Valley } \\
\text { 70C - Central New Mexico Highlands* } \\
\text { 70D - Southern Desert Foothills* }\end{array}$ \\
\hline & H - Central Great Plains Winter Wheat and Range Region & $\begin{array}{l}\text { 77A - Southern High Plains, Northern Part* } \\
\text { 77B - Southern High Plains, Northwestern Part* } \\
\text { 77E - Southern High Plains, Breaks* } \\
\text { 77D - Southern High Plains, Southwestern Part* }\end{array}$ \\
\hline & I - Southwest Plateaus and Plains Range and Cotton Region & $\begin{array}{l}\text { 81A - Edwards Plateau, Western Part* } \\
81 \mathrm{D} \text { - Southern Edwards Plateau* }\end{array}$ \\
\hline Western Mountains, Valleys, and Coast & $\begin{array}{l}\text { D - Western and Irrigated Region } \\
\text { E - Rocky Mountain Range and Forest Region }\end{array}$ & $\begin{array}{l}39 \text { - Arizona and New Mexico Mountains } \\
\text { 43B - Central Rocky Mountains } \\
\text { 47 - Wasatch and Uinta Mountains } \\
\text { 48A - Southern Rocky Mountains* } \\
\text { 48B - Southern Rocky Mountain Parks } \\
\text { 49 - Southern Rocky Mountain Foothills* }\end{array}$ \\
\hline & G - Western Great Plains and Irrigated Region & 62 - Black Hills \\
\hline
\end{tabular}




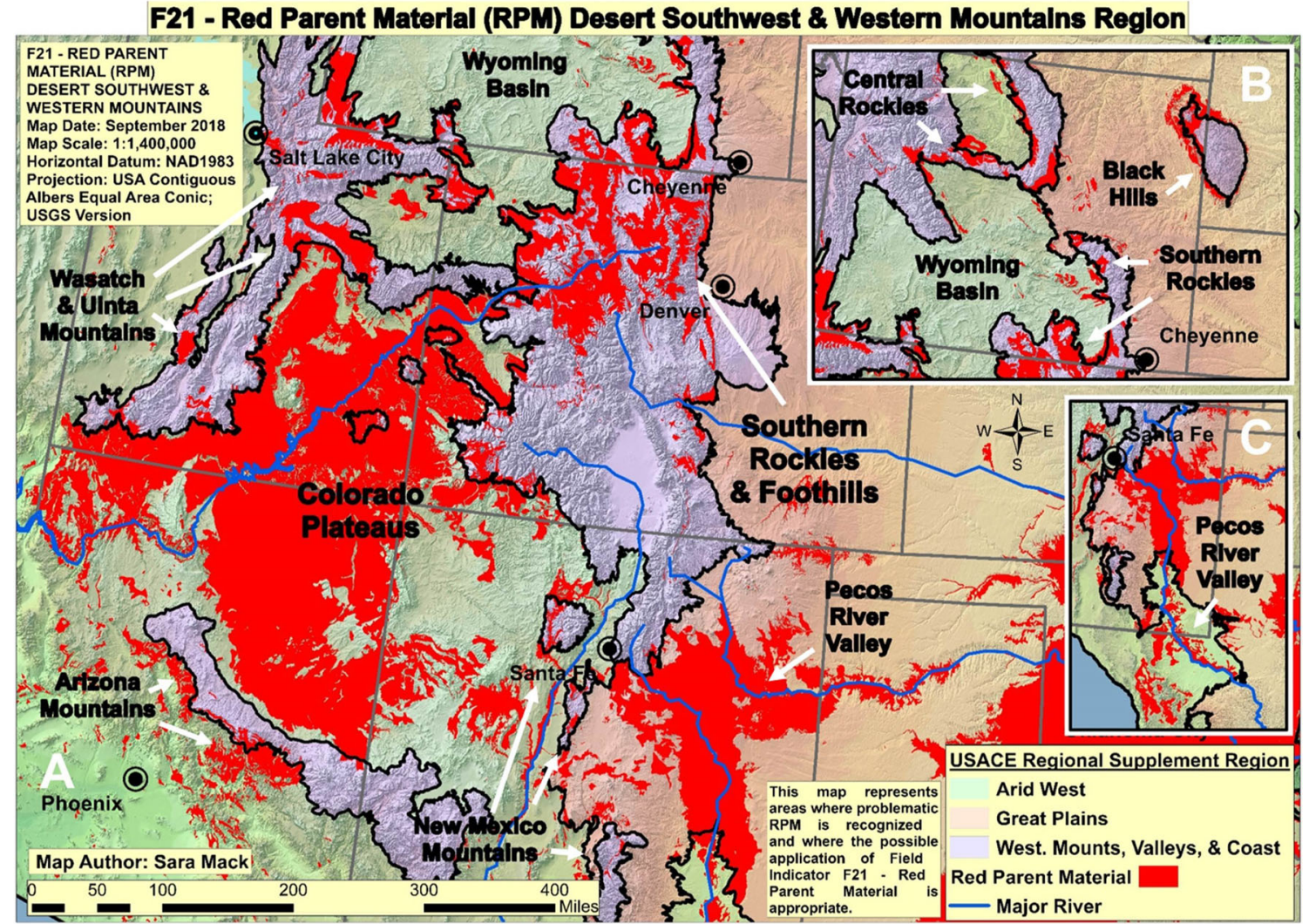

Fig. 5 Guidance map for recommended application of the F21- Red Parent Material field indicator in the Desert Southwest and Western Mountains RPM region. Red areas indicate locations with soils and geological formations where problematic RPM are possible

Table 14 Geological formations identified as potential problematic RPM within the Desert Southwest and Western Mountains RPM region
Geological Formation(s)

\begin{tabular}{lll}
\hline Abo Formation & Curtis Formation & Morrison Formation \\
Ankareh Formation & Dinwoody Formation & Naco Group \\
Arapien Formation & Dockum Formation & Navajo Sandstone \\
Arcturus Formation & Dockum Group & Nugget Sandstone \\
Artesa Sequence & Dolores Formation & Park City Formation \\
Artesia Group & Eagle Valley Formation & Pitoikam Formation \\
Graysburg Formation & Entrada Formation & Purgatoire Formation \\
Seven Rivers Formation & Entrada Sandstone & Quartermaster Formation \\
Tansill Formation & Fountain Formation & \\
Queen Formation & & \\
Yates Formation & Gardner Canyon Formation & Ralston Creek Formation \\
Bull Canyon Formation & Glen Canyon Formation & \\
Burro Canyon Formation & Glen Canyon Group & Recreation Red Beds \\
Bursum Formation & Glen Canyon Sandstone & Rudolfo Red Beds \\
Carmel Formation & Goose Egg Formation & San Rafael Group \\
Casper Formation & Grand Canyon Supergroup & Satanka Shale \\
Chinle Group & Nankoweap Formation & State Bridge Formation \\
Chinle Formation & Guadalupian Series & \\
Garita Creek Formation & Gypsum Spring Formation & Spearfish Formation \\
Redonda Formation & Ingleside Formation & Summerville Formation \\
Rock Point Formation & Hermit Formation & \\
Santa Rosa Formation & Hermit Shale & Sundance Formation \\
Shinarump Conglomerate Member & Jelm Formation & Supai Group \\
Chugwater Formation & Junction Creek Sandstone & Thaynes Formation \\
Chugwater Group & Kayenta Formation & Wanakah Formation \\
Chupadera Formation & Lykins Formation & Wingate Sandstone \\
Cutler Group & Lyons Formation & Woodside Formation \\
Cedar Mesa Sandstone & Lyons Sandstone & Woodside Shale \\
Cutler Formation & Maroon Formation & Vampire Formation \\
Organ Rock Formation & Mahogany Formation & Yeso Formation \\
Organ Rock Shale & Moenkopi Formation & Yeso Group \\
& Moenave Formation & Zuni Sandstone \\
\hline & &
\end{tabular}


Table 15 Soil series identified as potential problematic RPM that are associated with the Western Mountains, Valleys, and Coast regional supplement and surrounding foothills

\begin{tabular}{lllll}
\hline Soil Series & & & & \\
\hline Almy & Gypnevee & Perrypark & Sandark & Tilford \\
Barnum & Gystrum & Pimsby & Schooner & Tinytown \\
Bernal & Lamphier & Plome & Scout & Tours \\
Boyett & Lonetree & Podo & Sinkson & Vale \\
Chaseville & Miracle & Red Spur & Sixmile & White House \\
Cheesman & Monticello & Redbank & Southfork & Wycolo \\
Connerton & Nevee & Redridge & Spearfish & Yahmore \\
Contention & Neville & Redtom & Swint & \\
Fortwingate & Nuffel & Rekrop & Tampico & \\
Garber & Palma & Rizno & Thermopolis & \\
Gove & Peralta & Rule & Tieside & \\
\hline
\end{tabular}

feature identified in the maps and tables provided herein. These map and table resources define areas in which application of hydric soil indicator F21 is recommended. This can be accomplished by evaluating the study location using on-site data collection, Web Soil Survey, maps of geologic features, and the comprehensive descriptions of soil-geologic features in problematic RPM regions provided in Mack (2018). 2) Determine if the soil meets the criteria described in hydric soil indicator F21 - Red Parent Material. If the soil meets the requirements of F21 -Red Parent Material and occurs within a verified problematic RPM region, the presence of a hydric soil is confirmed. Alternatively, if the soil occurs outside of the guidance map boundaries, CCPI analysis can verify the presence of problematic RPM. 3) Determine if the location displays indicators of wetland hydrology and hydrophytic vegetation as described in the USACE wetland delineation manual and associated regional supplements. If the requirements of vegetation, and hydrology are documented in conjunction with 1) and 2) above, the presence of a wetland is confirmed.

Despite the collaborative, comprehensive approach utilized within the national mapping project, several important data
Table 17 Soil series identified as potential problematic RPM that are associated with Pecos River Valley

Soil Series

\begin{tabular}{llllll}
\hline Alama & Glenrio & La Lande & Los Tanos & Quay & San Jon \\
Bernal & Hagerman & Lacita & Montoya & Redona & Tucumcari \\
Berwolf & Hassell & Lacoca & Newkirk & Regnier & Tuloso \\
Conchas & Ima & Largo & Palma & Ribera & Walkon \\
\hline
\end{tabular}

limitations need to be considered when using RPM guidance maps and tables. Some limitations result from the broad scale of the mapping effort and inherent variability associated with soils and geologic source materials. To date, more than 24,000 soil series have been established nationwide (Rabenhorst 2016), which precludes the possible evaluation of CCPI for each soil series to verify their status as problematic RPM (or not). As a result, it is possible that problematic RPM may exist in other locations and additional CCPI analysis may be needed to confirm the presence of problematic RPM in those areas. Soil series in the potential problematic RPM range (CCPI of 30-40) were also included in RPM guidance maps if the soil series met criteria (provided above) that were utilized to generate lists of potential RPM soil series during the mapping phases of the project. This was done to avoid exclusion of potential problematic RPM associated with materials that displayed some degree of color change resistance. Additionally, RPM guidance maps were generated using the U.S. General Soil Map (STATSGO2) Database, which is designed for mapping purposes on regional, multi-state scales $(1: 250,000)$. Thus, map units identified as problematic RPM are intended to reflect areas where problematic RPM may be present, and onsite verification is required prior to application of the F21 - Red Parent Material hydric soil field indicator. Also, areas included in the RPM guidance maps required $5 \%$ or more of a map unit component to contain a soil series identified as potential problematic RPM as defined in the U.S. General Soil Map (STATSGO2) Database. As previously noted, the approach intentionally did not consider other
Table 16 Soil series identified as potential problematic RPM that are associated with the Colorado Plateaus

\begin{tabular}{|c|c|c|c|c|c|}
\hline \multicolumn{6}{|l|}{ Soil Series } \\
\hline Acree & Epikom & Mack & Monue & Remorris & Tours \\
\hline Aneth & Fortwingate & Mellenthin & Naplene & Ribera & Wetherill \\
\hline Arches & Gladel & Mespun & Nuffel & Rizno & Whitecanyon \\
\hline Arntz & Grassytrail & Mido & Padilla & Robroost & Winkel \\
\hline Barx & Hadden & Milok & Palma & Sandark & Yahmore \\
\hline Begay & Hagerman & Mivida & Parkelei & Simel & \\
\hline Blackston & Hassell & Moenkopie & Penzance & Strych & \\
\hline Brinkerhoff & Hillburn & Mokaac & Plome & Suwanee & \\
\hline Burnswick & Jocity & Monogram & Redbank & Tintero & \\
\hline Caval & Leanto & Monticello & Regracic & Tobler & \\
\hline
\end{tabular}


factors relevant to hydric soils (or wetlands) such as drainage class or slope, but sought to encompass all areas where problematic RPM was likely to occur. Similar limitations are related to the geologic datasets and mapping, including discontinuity between states boundaries regarding geologic mapping conventions and other factors.

Future work should focus on refining national RPM guidance maps based upon application of the hydric soil field indicator F21 - Red Parent Material by wetland practitioners and soil scientists. Increased consultation and collaboration with wetland, soil, and geological scientists should also be pursued in areas where problematic RPM has been identified to further correlate soils and geological datasets with problematic RPM at/across state boundaries. This is especially true for areas in the South-Central and Desert Southwest and Western Mountains problematic RPM regions where sample submission was limited compared to other areas. Further research could also incorporate datasets specifically relevant to wetlands to align the maps presented herein with the occurrence of hydric soils developed in problematic RPM. For example, evaluation of the problematic RPM maps using hydric soils lists, drainage class designation, U.S. Fish and Wildlife Service's National Wetlands Inventory data, and other tools may prove useful at various spatial scales. Also, utilization of higher resolution soils and geological datasets (where available) could further refine results.

\section{Conclusions}

Hydric soil field indicator, F21 - Red Parent Material, has been approved for nationwide testing in soils derived from problematic RPM soils that are resistant to redox-induced color changes. The maps and tables provided allow for rapid and defensible application of hydric soil field indicator F21 - Red Parent Material across the United States, whereas the spatial occurrence and extent of problematic RPM soils was previously unknown. As a result, four problematic RPM regions (Northeast and Mid-Atlantic, Great Lakes, South-Central, and Desert Southwest and Western Mountains) were identified for the application of the F21- Red Parent Material hydric soil field indicator. Within each of these problematic RPM regions, diverse groups of soils and parent materials exhibited problematic RPM characteristics, however all problematic RPM areas occurred in association with sedimentary, hematite-rich "red bed" formations, and the recently deposited (alluvial, colluvial, and glacial) materials derived from them. The problematic RPM maps, tables, and supplemental guidance link soil series, geologic formations, and parent materials containing problematic RPM, allowing users to rapidly identify potential RPM soils through a variety of pathways. Based on these findings, revisions to the F21 - Red Parent Material will be proposed recommending either the application of
CCPI data or the occurrence of potential problematic RPM soils within one of the problematic RPM regions described herein prior to the use of the indicator. The collaborative effort among universities, agency staff, soil archives, and field practitioners provided for a national scale mapping effort, improving approaches to hydric soil identification and accurate wetland delineation across a large and diverse geographic area.

Acknowledgements This work was supported by the USACE Wetland Regulatory Assistance Program (WRAP) administered through the Engineer Research and Development Center, Environmental Laboratory in Vicksburg, MS. We would like to thank all USDA-NRCS, USACE, academic, state agency, and private sector participants who submitted soil samples and comments, and we are particularly indebted to our colleagues Doug Wysocki, Steve Monteith, Michelle Etmund and Amber Shinn at the KSSL in Lincoln, NE for their tremendous support. Without the time, help, and local expertise provided by over 50 individuals, this nationwide collaborative effort would not have been possible.

Open Access This article is distributed under the terms of the Creative Commons Attribution 4.0 International License (http:// creativecommons.org/licenses/by/4.0/), which permits unrestricted use, distribution, and reproduction in any medium, provided you give appropriate credit to the original author(s) and the source, provide a link to the Creative Commons license, and indicate if changes were made.

\section{References}

Baker AA, Dane CH, Reeside JB Jr (1947) Revised correlation of Jurassic formations of parts of Utah, Arizona, New Mexico, and Colorado: geological notes. American Association of Petroleum Geologists Bulletin 31(9):1664-1668

Berkowitz JF (2011a) Regionalizing the Corps of Engineers wetland delineation manual: process overview and status report. National Wetland Newsletter 33:24-28

Berkowitz JF (2011b) Recent advances in wetland delineation - implications and impact of regionalization. Wetlands 39(3):593-601

Berkowitz JF, Sallee JB (2011) Investigating problematic hydric soils using water table measurements, IRIS tubes, soil chemistry, and application of the hydric soils technical standard. Soil Science Society of America Journal 75(6):2379-2385

Bigham JM, Ciolkosz EJ, Blodgett RH, Crabaugh JP, McBride EF (1993) The color of red beds: a geologic perspective. p. 127-159. In Soil color. Soil science Society of America Special Publication no. 31. Soil Science Society of America Press. Madison, WI

Branson EB (1927) Triassic-Jurassic "red beds" of the Rocky Mountain region. Journal of Geology 35(7):607-630

Craft CB (2000) Biology of Wetland Soils. p. 107-136. In Wetland soils: Genesis, hydrology, landscapes, and classification. M. Vepraskas and C. Craft (eds.). CRC Press. Boca Raton, FL

Elless MP, Rabenhorst MC, James BR (1996) Redoximporphic features in soils of the Triassic Culpeper basin. Soil Science 161(1):58-69

Environmental Laboratory (1987) Corps of Engineers wetland delineation manual. United States Army Engineer Waterways Experiment Station, Vicksburg, MS.

Federal Register (1994) Changes in hydric soils of the United States. Department of Agriculture, Washington, DC 
Ford E (2014) Investigating problematic hydric soils derived from redcolored glacial till in the Hartford Rift Basin of Connecticut. Masters Thesis. University of Rhoade Island. South Kingstown, RI

Krynine P (1949) Section of the geology and mineralogy: the origin of red beds. Transactions of the New York Academy of Sciences 11(3):6068

Lucas SG, Anderson OJ (1998) Jurassic stratigraphy and correlation in New Mexico. New Mexico Geology 20(4):97-104

Lucas SG, Anderson OJ, Love DW (1993) Stratigraphy of the PermianTriassic boundary in southeastern New Mexico and West Texas. In Geology of the Carlsbad region, New Mexico and West Texas. West Texas, New Mexico geological society 44th field conference guidebook 44: 219-230

Lusardi BA (1997) Minnesota at a glance: quaternary glacial geology. Minnesota geological Survey University of Minnesota. St. Paul, MN

Mack SC (2018) Identifying problematic hydric soils derived from red parent materials in the United States. Masters thesis. University of Maryland. College Park, MD

Mokma DL, Sprecher SW (1994) Water table depths and color patterns in soils developed from red parent materials in Michigan, USA. Catena 22(4):287-298

Niroomand G, Tedrow JFC (1990) Influence of parent material on gley formation. Pochvovedenie 8:32-49

Petersen GW, Lee GB, Chesters G (1967) A comparison of red clay glacio-lacustrine sediments in northern and eastern Wisconsin. Wisconsin Academy Science, Arts, and Letters 56:185-196

Pipiringos GN (1968) Correlation and nomenclature of some Triassic and Jurassic rocks in south-Central Wyoming. United States geological survey professional paper 594-D

Rabenhorst MC (2011) Pedogenesis of Hydric Soils - Hydropedology. In A guide to hydric soils in the Mid-Atlantic Region, Version 2.0. LM Vasilas and BL Vasilas (eds.). United States Department of Agriculture-Natural Resources Conservation Service. Morgantown, WV

Rabenhorst MC (2016) A half century of changes in soil taxonomy. Soil Science Society of America Journal 80:839-844

Rabenhorst MC, Parikh S (2000) Propensity of soils to develop redoximorphic color changes. Soil Science Society of America Journal 64(5):1904-1910

Reddy KR, DeLaune RD (2008) Biogeochemistry of wetlands: science and applications. CRC Press, Boca Raton, FL

Reeside JB (1929) Triassic-Jurassic 'red beds' of the Rocky Mountain region: a discussion. Journal of Geology 37(1):47-63

Robinette C, Rabenhorst MC, Vasilas L (2011) Chapter 10. Identifying problem hydric soils in the Mid-Atlantic Region In A guide to hydric soils in the Mid-Atlantic Region, Version 2.0. LM Vasilas and BL Vasilas (eds.). United States Department of Agriculture-Natural Resources Conservation Service. Morgantown, WV

Schwertmann U (1993) Chapter 4. Relationships between iron oxides, soil color, and soil formation. p. 51-69. In Soil Science Society of America special publication 31: Soil color. Soil Science Society of America Press. Madison, WI
Sirkin LA (1986) Palynology and stratigraphy of cretaceous and Pleistocene sediments on Long Island, new work - a basis for correlation with New Jersey coastal plain sediments. U.S. Department of the Interior. In: Geological survey. D.C, Washington

Stolt MH, Lesinski BC, Wright W (2001) Micromorphology of seasonally saturated soils in carboniferous glacial till. Soil Science 166(6): 406-414

Tiner R (2016) Wetland indicators: a guide to wetland identification, delineation, classification, and mapping. CRC Press, Boca Raton, FL

Turner P (1980) Continental red beds. Elsevier, New York, NY

United States Army Corps of Engineers (2010a) Regional supplement to the Corps of Engineers wetland delineation manual: Great Plains Region Version 2.0. Wakeley JS, Lichvar RW, Noble CV (eds.). U.S. Army Engineer Research and Development Center, Vicksburg, MS.

United States Army Corps of Engineers (2010b) Regional supplement to the Corps of Engineers wetland delineation manual: Western Mountains, Valleys, and Coast Region Version 2.0. Wakeley JS, Lichvar RW, Noble CV (eds.). U.S. Army Engineer Research and Development Center, Vicksburg, MS.

United States Army Corps of Engineers (2012) Regional supplement to the Corps of Engineers wetland delineation manual: Eastern Mountains and Piedmont Region (Version 2.0), Berkowitz JF, Wakeley JS, Lichvar RW, Noble CV (eds.). U.S. Army Engineer Research and Development Center, Vicksburg, MS.

United States Department of Agriculture - Natural Resources Conservation Service (2006) Land resource regions and major land resource areas of the United States, the Caribbean, and the Pacific Basin. U.S. Department of Agriculture Hanbook 296. United States Department of Agriculture. Washington, DC

United States Department of Agriculture, Natural Resources Conservation Service (2017) Field Indicators of Hydric Soil in the United States, Version 8.0, USDA, NRCS, In cooperation with the National Technical Committee for Hydric Soils Washington, DC

Van Houten FB (1973) Origin of red beds: a review-1961-1972. Annual Review of Earth and Planetary Sciences 1:39-61

Vasilas LM, Berkowitz JF (2016) Identifying hydric soils in the landscape. In Wetland soils: genesis, hydrology, landscapes, and classification. M. Vepraskas and C. Craft (eds.). CRC Press. Boca Raton, FL

Vepraskas MJ, Sprecher SW (1997) Overview of aquic conditions and hydric soils. In Soil Science Society of America special publication 50. Aquic Conditions and Hydric Soils: The problem soils. Soil Science Society of America Press. Madison, WI

Wakeley JS (2002) Developing a "Regionalized" version of Corps of Engineers wetlands delineation manual: Issues and recommendations. United States Army Corps of Engineers, Environmental Laboratory, U.S. Army Engineer Research and Development Center, Vicksburg, MS.

Wheeler DB, Thompson JA, Bell JC (1999) Laboratory comparison of soil redox conditions between red soils and brown soils in Minnesota, USA. Wetlands 19(3):607-616 